\title{
The Relationship between School Administrators Personalities and Servant Leadership Behaviours
}

\author{
Mehmet Hilmi Sağlam ${ }^{1}$, Yusuf Alpaydın ${ }^{1}$ \\ Correspondence: Mehmet Hilmi Sağlam, Educational Sciences Instıtution, Marmara University, Turkey.
}

Received: June 11, 2017

doi:10.11114/jets.v5i8.2474
Online Published: July 21, 2017

URL: https://doi.org/10.11114/jets.v5i8.2474

\begin{abstract}
In a globalized world, people's financial opportunities are increasing. However, their spiritual and moral behaviour is diminishing. This situation can be seen in both people and institutions, especially in the education sector. Servant Leadership, which presents a new perspective on this humanitarian crisis, is a modern leadership approach. An effective and successful school comprises managers with strong personalities and effective leadership methods. The main purpose of this research is to examine the relationship between the personalities of school administrators and their servant leadership behaviours. A correlational research model was used in the research. The participants constituted 14.135 teachers working in schools in the province of Denizli, a city in Turkey, in the academic year of 2016-2017. The sample comprised 327 teachers selected using the convenient easy sampling method. A personal information form prepared by the researcher, compriseing the Servant Leadership Scale and the Adjective Based Personality Test (ABPT) was used in the research. The research data was analysed with the IBM SPSS 21.0 package software program. As a result of the analyses made, a high positive correlation was found between school administrator personalities and Servant Leadership behaviours $(\mathrm{r}=.764)$.
\end{abstract}

Keywords: leadership, servant leadership, personality, administrator

\section{Introduction}

Leadership is a cross-disciplinary issue. Therefore, many areas such as psychology, education, economics and sociology have been very interested in leadership and have conducted research on this subject. The history of the examination of leadership dates back to Plato's Republic work from the 400s BC (Lunenburg \& Ornstein, 2013). For this reason it should not be surprising that the concept of leadership is as diverse as the people involved in the work (Hoy \& Miskel, 2015). Although there are some conceptual disagreements, a definition of leadership, accepted by most experts, is as follows: 'Leadership is the process by which the individual influences other group members to achieve defined achievement or organizational goals' (Yukl, 2010). However, the development in many areas in the modern world has brought many needs along with it. In particular, the managers who work in educational institutions are the ones most affected by this situation.

Managers who move by means of the traditional approach and who prefer restrictions, control and authority, face, difficulties when directing people. In this era, where open policies, trust-based relationships, leadership practices for empowerment and guidance are important, there is a need for more instructive, helpful and sharing of knowledge leaders of this type of authoritarian and pragmatist leadership (Saylı \& Baytok, 2013). In all organizations, the goal of life is to serve others directly or indirectly. The relationships that arise in the face of service will move benefits, commerce and services into action and enable ideals to be realized at the highest level (Casson, 2006).

At first glance, the words 'Leader' and 'Servant' seem to have opposite meanings. When these two opposites are brought together in a creative and meaningful way, a paradox emerges and a new sense of leadership is created (Yllmaz, 2013). The term servant leadership, first used by Greenleaf (1970), has attracted many researchers. Some researchers, interested in the servant leadership approach following Greenleaf (1970), include Graham (1991), Spears (1995), Farling (1999), Laub (1999), Page and Wong (2000), Russell (2001), Patterson (2003), Dennis and Bocernea (2005), Joseph and Winston, (2005), Wong and Davey (2007), Vinod and Sudhakar (2011).

Servant leadership is a leadership understanding that values people, develops them, helps them to act originially, leads people's well-being, and encourages the sharing of power and status for each individual's good (Laub, 1999). In other words, it is a leader that serves to contribute to the development and interest of others in order to accomplish the tasks 
and objectives comprising the primary purpose of the organization. The way in which the concept of traditional servility is not service-oriented, it also cannot be described as servant leadership (Page \& Wong, 2000). A servant leader, on the basis of his legal power, does not want to be forced to do something; however, he/she rather convinces others of what he/she wants to do (Joseph \& Winston, 2005). According to Fındıkçı (2012), the servant leader is a heartfelt person who is the passenger of the love path, valuing this before everything else.

It is difficult to define the leadership personality. There are multiple definitions of the leadership personality in the literature. Burger (2011) defines personality as set of individually-driven personal behaviour processes and consistent behaviour patterns. In other words, personality is the collective characteristic of the individual, consistent and structured, which distinguishes the individual from others (Yazgan Inanc \& Yerlikaya, 2012). In another definition, personality is information about the individual's mental, physiological and mental characteristics. The person's personality with respect to others is that he has certain characteristics and roles in society (Eren, 2015). Apart from these authors, the definition of personality varies according to the theory under scrunity. While psychoanalytic theory explains personality through conscious and unconscious processes, cognitive approaches focus on mental processes and biological approaches focus on inheritance and genes.

Leadership is a product of personality. The development and change of personality can directly influence leadership. Effective and successful administrators can ensure that schools are effective and successful. According to Zel (2011), this is because the role played by personality factors in terms of person-organization integration is very important. Considering today's conditions and leadership approaches, it can be said that a leader should have intelligence, credibility, accuracy, conceptual ability, empathy, listening skills and influence as general personality traits (Saylı \& Baytok, 2013). As can be seen, the place of the education manager in the system in terms of leadership and personality is very important. Posture, behaviour and attitude affect the entire system and organization. Being an effective and productive school starts with the presence of effective and efficient teachers and administrators. For this reason, in this research, teachers were given the Servant Leadership Scale and the Adjective Based Personality Test. The intent was to evaluate the school administrators' personalities and servant leadership behaviours through the eyes of teachers. This assessment aims to contribute to the search and comparison of teachers' perceptions of executives in terms of servant leadership and personality and integrate with the ideal of servant leadership in responding to the urgent needs of managers in educational institutions in the light of acquired the information. In accordance with this purpose, the statement of the problem is as follows: 'Is there a meaningful relationship between administrators' personalities and Servant Leadership behaviours according to teacher perceptions?'

\section{Method}

\subsection{Research Design}

The research was a correlational research study. Therefore, the behaviours of school administrators were evaluated in terms of teacher observations.

The screening approach, which aims to determine the presence of coexistence between two or more variables, is a correlational scan. Correlation studies show that variables vary together; if there is a change, the method tries to determine how the change occurs (Karasar, 2008, p. 86).

\subsection{Population and Sample}

The participants of the research constituted 14.135 teachers working in schools in the province and districts of Denizli (a city in Turkey) in the academic year of 2016-2017. The sample comprised 327 teachers who were selected by the convenient easy sampling method from an unsorted sampling technique. A total of 214 (65.4\%) of the participants were female, while 113 (34.6\%) were male.

This method of sampling includes all currently existing, readily or voluntarily sampled persons. This method gives speed and practicality to the research. This is because, in this method, the researcher chooses a situation that is accessible in proximity. In other words, it contains samples that the researcher can reach (Yıldırım \& Şimşek, 2013, p.121).

\subsection{Data Collection Tool and Application}

The Servant Leadership Scale developed by Reed, Vidaver-Cohen and Colwell in 2011 and adapted to Turkish by Demir, Konan and Karakus (2015) was used. After linguistic validity studies of the scale were developed and it was found that they had linguistic equivalence, the opinions of experts working in two different universities were obtained for scope validity. Explicit Factor Analysis and Confirmatory Factor Analysis were performed for construct validity. The Split-Half correlation coefficient and Cronbach's Alpha internal consistency coefficient were used to examine the reliability of the scale. The Cronbach Alpha internal consistency coefficient was .888. Using the Split-Half method, the first half was .851 and the second half was .778 . The correlation between the forms was found to be .693 in total. The 
scale consisted of the same number of dimensions (five); however, it had fewer materials (20 items) in Turkish culture. Consequently, it was proven to be a valid and reliable measurement tool for measuring School Leaders' Servant Leadership qualities. The sub-factors and items included the following dimensions: Interpersonal Support (1, 2, 3, 4 and 5), Building Community (6, 7, 8, 9, 10 and 11), Altruism (12, 13 and 14), Egalitarianism (15, 16 and 17), Moral Integrity $(18,19$ and 20). The interpersonal support dimension includes features such as helping others, listening to others, sharing decision-making processes with people affected by decisions and acting with respect for followers. The community building dimension refers to the ability of the leader to form a community both inside and outside the organization. The altruism dimension is at the centre of this leadership approach and includes features such as not anticipating the desires of others and sacrificing personal benefits. The egalitarianism dimension includes features such as not being superior to others in the leader's organization, receiving contributions from all levels and accepting criticism. The moral integrity dimension includes features such as trusting, promoting transparency and honesty, and not deceiving anyone for personal purposes. The current 20-item Servant Leadership Scale, which was finalized on the basis of researchers' practices, was included in the research.

The Adjective-based Personality Scale (ABPT) was developed by Bacanlı et al. (2009). This research performed a Principal Component Factor Analysis on the data obtained from a group of 285 people to test the validity of the structure of the ABPT. As a result of the analysis, these five factors covering 40 items revealed $52.63 \%$ of the variance belonging to ABPT. The internal consistency coefficients of the dimensions of ABPT were found to be in the range of .73 to .89 . The lowest internal consistency coefficient was .73 and the highest internal consistency coefficient was .89 and the extrinsic dimension was found to be emotional imbalance. It was determined that ABPT had the highest correlation coefficient $(\mathrm{r}=.86, \mathrm{p}<.01)$ while the lowest correlation coefficient belonged to Experimental Openness $(\mathrm{r}$ $=.68, \mathrm{p}<.01)$ in terms of test retest reliability coefficient. Thus, the ABPT scale was included in the survey.

\subsection{Analysis}

The statistical package program SPSS (Statistical Package for Social Sciences, Version 21.0) was used for statistical analyses.

Demographic variables (gender, marital status, education level, education status and duration of service) were accepted as independent variables in the survey. The descriptive frequency and percentage values of the demographic variables were calculated.

Independent group t-tests and one way ANOVA were used to analyse the demographic data of the teachers who constituted the sample group. In cases where the difference in the results of the one-way ANOVA test was significant, the Scheffe test was conducted to determine the source of the differences, i.e. which groups were included.

The correlation between the scores obtained for the total of the scales and their sub-factors was examined using Pearson Correlation Analysis.

The sample was based on a 95\% confidence interval and 0.05 error and the findings were presented in tabular form for the purpose as appropriate.

\section{Results}

Results of Pearson correlation analysis to determine relationships between ABPT scale sub-dimensions and servant leadership scale total score are given at Table 1.

Table 1. Relationships between ABPT scale sub-dimensions and servant leadership scale total score

\begin{tabular}{llll}
\hline \multirow{2}{*}{ ABPT Scale Sub-Dimensions } & \multicolumn{4}{l}{ Servant Leadership Scale Total Score } \\
\cline { 2 - 4 } & $\mathrm{N}$ & $\mathrm{R}$ & $\mathrm{P}$ \\
\hline Neuroticism & 327 & -.572 & .000 \\
Extraversion & 327 & .665 & .000 \\
Openness to Experience & 327 & .795 & .000 \\
Agreeableness & 327 & .772 & .000 \\
Conscientiousness & 327 & .642 & .000 \\
\hline
\end{tabular}

$* * p<.001$

When Table 1 is examined, Pearson correlation analysis revealed a negative correlation between ABPT Scale's Emotional Unbalance/Neuroticism sub-dimension and the Servant Leadership Scale total score. $(\mathrm{r}=-.572 ; \mathrm{p}<.001)$. In addition, it was also seen that for other sub-dimensions of the ABPT Scale, a significant positive correlation was found. There is a significant relationship that is positive at a moderate level between the ABPT Scale Extraversion 
sub-dimension and the Servant Leadership Scale total score $(\mathrm{r}=.665 ; \mathrm{p}<.001)$. There is a significant relationship that is positive at a high level between the ABPT Scale Openness to Experience sub-dimension and the Servant Leadership Scale total score $(\mathrm{r}=.795 ; \mathrm{p}<.001)$. There is a significant relationship that is positive at a high level between the ABPT Scale Agreeableness sub-dimension and the Servant Leadership Scale total score $(r=.772 ; p<.001)$. There is a significant relationship that is positive at a moderate level between the ABPT Scale Conscientiousness sub-dimension and the Servant Leadership Scale total score $(r=.642 ; \mathrm{p}<.001)$. The highest correlation was found between the Openness to Experience sub-dimension and the Served Leadership Scale total score $(r=.795 ; \mathrm{p}<.001)$. The lowest correlation was found between the Conscientiousness sub-dimension and the Servant Leadership Scale total score ( $\mathrm{r}$ $=.642 ; \mathrm{p}<.001)$.

Results of Pearson correlation analysis to determine relationships between ABPT scale sub-dimension and servant leadership scale sub-dimension scores are given at Table 2 .

Table 2. Relationships between ABPT scale sub-dimension and servant leadership scale sub-dimension scores

\begin{tabular}{|c|c|c|c|c|c|c|c|c|c|c|c|c|c|}
\hline Variables & $\mathrm{X}$ & 1 & 2 & 3 & 4 & 5 & 6 & 7 & 8 & 9 & 10 & 11 & 12 \\
\hline 1- IS & 2,39 & 1 & $.901 *$ & $.826^{*}$ & $.855^{*}$ & $.837 *$ & $.951 *$ & $-.556^{*}$ & $.652 *$ & $.775^{*}$ & $.742 *$ & $.641 *$ & $.739 *$ \\
\hline 2- BC & 2,16 & & 1 & $.850 *$ & $.849 *$ & $.869 *$ & $.959 *$ & $-.538^{*}$ & $.636^{*}$ & $.769 *$ & $.750 *$ & $.633^{*}$ & $.734 *$ \\
\hline 3-AL & 2,39 & & & 1 & $.845^{*}$ & $.860 *$ & $.920 *$ & $-.504 *$ & $.635^{*}$ & $.772 *$ & $.757 *$ & $.605 *$ & $.744 *$ \\
\hline 4- E & 2,38 & & & & 1 & $.849 *$ & $.923 *$ & $-.599 *$ & $.593 *$ & $.751 *$ & $.759 *$ & $.574 *$ & $.690 *$ \\
\hline 5-MI & 2,13 & & & & & 1 & $.928 *$ & $-.594 *$ & $.629 *$ & $.741 *$ & $.795 *$ & $.630 *$ & $.723 *$ \\
\hline 6-Servant & 2,28 & & & & & & 1 & $-.586^{*}$ & $.670 *$ & $.809 *$ & $.800 *$ & $.656^{*}$ & $.764 *$ \\
\hline Leadership & & & & & & & & & & & & & \\
\hline $\begin{array}{l}\text { (Total) } \\
7-N\end{array}$ & $\begin{array}{l}3,34 \\
5,16\end{array}$ & & & & & & & 1 & $-.345^{*}$ & $\begin{array}{l}-.494 * \\
847 *\end{array}$ & $\begin{array}{l}-.657^{*} \\
601 *\end{array}$ & $\begin{array}{l}-.393^{*} \\
812 *\end{array}$ & $\begin{array}{l}-.299 * \\
909 *\end{array}$ \\
\hline $8-E$ & 5,03 & & & & & & & & & 1 & $.800 *$ & $.800 *$ & $.934 *$ \\
\hline 9-OE & 5,38 & & & & & & & & & & 1 & $.616^{*}$ & $.740 *$ \\
\hline $10-\mathrm{A}$ & 5,72 & & & & & & & & & & & 1 & $.861 *$ \\
\hline $11-\mathrm{C}$ & 4,97 & & & & & & & & & & & & 1 \\
\hline $\begin{array}{l}\text { 12-Personality } \\
\text { (Total) }\end{array}$ & & & & & & & & & & & & & \\
\hline
\end{tabular}

List of Abbreviations used in Tabel 2:

Servant Leadership Scale Sub-Dimension

IS: Interpersonal Support

BC: Building Community

AL: Alturism

E: Egalitarianism

MI: Moral Integrity
ABPT Scale Sub-Dimension

$\mathrm{N}$ : Neuroticism

E: Extraversion

OE: Openness to Experience

A: Agreeableness

S: Conscientiousness

When Table 2 was examined using Pearson Correlation Analysis, a negative relationship between the ABPT Scale Neuroticism sub-dimension and both ABPT sub-dimensions and Servant Leadership sub-dimensions was found. The lowest negative correlation was found between the ABPT Scale total score and the Neuroticism sub-dimension $(\mathrm{r}=$ $-.299 ; \mathrm{p}<.001)$. The highest negative correlation was found between the ABPT Scale Neuroticism sub-dimension and the ABPT Scale's Altruism sub-dimension $(r=-.657 ; \mathrm{p}<.001)$. The lowest positive correlation was found between the Servant Leadership scale's Egalitarianism sub-dimension and the ABPT scale's Conscientiousness sub-dimension ( $\mathrm{r}$ $=.574 ; \mathrm{p}<.001)$. The highest positive correlation was found between the Servant Leadership scale's Building Community sub-dimension and the Servant Leadership scale total score $(r=.959 ; \mathrm{p}<.001)$. The highest correlation in the subscales was found between the Servant Leadership scale's Interpersonal Support sub-dimension and the Servant Leadership scale's Community Building sub-dimension $(\mathrm{r}=.901 ; \mathrm{p}<.001)$.

When we look at the average in Table 2, the highest average for the ABPT scale is Conscientiousness level in the Personality sub-dimension $(\overline{\mathrm{X}}=5,72)$. This shows that teachers consider most managers to have responsible personality traits. The highest average in the Servant Leadership scale is Interpersonal Support and Altruism levels in the Servant Leadership sub-dimension $(\overline{\mathrm{X}}=2,39)$. Participants expressed that support from administrators and teachers in leadership were self-sacrificing. 
Table 3. Regression analysis for personality and servant leadership total scores

\begin{tabular}{llrrrr}
\hline Variable & $\mathrm{B}$ & Standart Error & $\beta$ & $T$ & $p$ \\
\hline Constant & 6,47 & .199 & - & 32,519 & .000 \\
Personality & .844 & .040 & .764 & 21,353 & .000 \\
\hline $\mathrm{R}=.764$ & $\mathrm{R}^{2}=.584$ & $\mathrm{~F}=455,931$ & \multicolumn{3}{c}{$P=.000$} \\
\hline
\end{tabular}

As shown in Table 3, a regression analysis was conducted to determine the extent to which personality traits perceived by teachers predicted servant leadership behaviours. The regression model established between personality functioning as an independent variable and the level of servant leadership behaviour, functioning as a dependent variable, was statistically significant $(F=455,931 ; p<.001)$. It was also found that the personality variable was a predictor of the servant leadership variable $\left(\mathrm{R}=.26 ; \mathrm{R}^{2}=.07 ; \mathrm{p}<.001\right)$. It can be seen that, personality considered as an independent variable can explain the dependent variable (Servant Leadership Behavior) by $58.4 \%$. As a matter of fact, there is a positive relationship between perceived personality and servant leadership behavior. This relationship was found to be statistically significant.

The results of the research show that there was a significant positive correlation between the personalities of the school administrators and servant leadership behaviours. This shows that personality can explain servant leadership behaviours by $58.4 \%$.

\section{Conclusion and Discussion}

The purpose of this research was to determine the relationship between the personality of administrators and the servant leadership behaviours. In the literature, there is no research that has investigated the relationship between the personality of administrators and the servant leadership behaviours. This gap in the literature was the main reason for conducting this research. This research showed that there is significant positive relationship between servant leadership behaviours and personality. Servant leadership behaviours have a negative relationship with the neurotic personality while the other sub-dimensions have a positive relationship with servant leadership. These findings are consistent with the existing body of literature. For instance, Valentine (2007) found a high level of correlation between these variables in his doctoral dissertation entitled, 'The relationship between servant leadership, school culture and student achievement'. Servant leadership can thus be seen to exert a high level of impact on school culture and student achievement.

Black (2007) investigated the relationship between school climate and servant leadership. A total of 231 full-time teachers working in Catholic schools in Ontario were assessed. It was found that there was a positive relationship between school climate and custodial leadership as a result of applied scales.

Parolini (2007), as a result of his doctoral research, collected the distinction of servant leadership and transformational leadership approach across five areas. These included morality, focus, motive and mission of the leader, development and effect. Paroloni explained the difference between the servant leader and the transformational leader. While the transformational leader showed collective and organizational sacrifice, the servant leader showed devoted service and sacrifice for each of the individuals in the organization.

Brown (2010) conducted a survey to evaluate school principals and raise awareness by referring to the views of high school teachers residing in the coastal and rural areas of Virginia. As a result of the research, it was pointed out that current school leaders can better direct and manage their school communities if they adapt their servant leadership practices to the characteristics of their communities.

Judge, Bono, Ilies and Gerhardt (2002) found positive relationships with other dimensions on the neuroticism sub-dimension. Their result complements the result of the current research. However, the lowest level of relationship was found in the agreeableness sub-dimension. In current research, conscientiousness has been found to relate to agreeableness. Bartone et al. (2009) confirmed the importance of psychological well-being, extraversion and responsibility as factors affecting leadership effectiveness. Their results also showed that different personality factors may influence leadership in different organizational contexts in the five-factor personality theory. For example, extraversion is more effective in social and active working environments, while conscientiousness is more striking in the academic field. They also found positive relationships with other sub-dimensions besides neuroticism. These findings align with the results obtained in the present survey.

Cavazottea, Morenob and Hickmann (2011) found that leadership effectiveness is a direct function of a leader's transformation behaviours and that individual differences (experience, intelligence and conscientiousness) working through transformational behaviours are indirect functions. In addition, there was a negative effect of neuroticism on leadership effectiveness. Likewise, in the present research, neuroticism was found to have a negative effect on servant leadership. 
Kalshoven, Hartog and Hoogh (2011) found that conscientiousness and agreeableness factors relate to ethical leadership in the 'Ethical Leadership Behaviour and Five Factors of Personality' study. Moreover, ethical leadership was found to have no relation to openness in order to experience and extraversion. The dimension of conscientiousness parallels our own research findings. A high level of relationship was found between openness to experience, extraversion and servant leadership. These results differ from the results found by Kalshoven, Hartog and Hoogh (2011). The main difference is that research for these respective studies was performed with respect to different types of leadership.

Cigdem (2013) conducted a qualitative study with 5 managers in his thesis titled 'A Qualitative Research on the Factors that Lead the Leader's Behaviour to Servant Leadership'. As a result of the research, it was determined that the factors that lead the managers to exhibit servant leadership behaviours are values, intrinsic motivation, experience, mentor effect, self realization, altruism, unrequited love, awareness and the desire to affect others' lives positively and to be beneficial to others. These findings are closely related to the characteristics of being useful to others, values, experience, self-realisation, unrequited love, and the desire to look at others positively. Therefore, the positive relationship between the personality of the administrators obtained in our research and the servant leadership behaviours can be seen to be similar.

In this research, there was a strong positive relationship between the personalities of managers and the servant leadership behaviours. According to this result, improving the personality of an executive will indirectly improve that manager's ability to perform servant leadership.

\section{Suggestions}

According to the results of the research, there is a significant positive relationship between the personality of school administrators and servant leadership behaviours. We can thereby expect administrators to be able to participate in seminars and training to improve their personality and servant leadership behaviours. Alternatively, such trainings could be included in the education system in a programmatic way.

The relationship and communication of teachers and administrators should be strong. This is necessary because the main problems in the education sector are due to inaccurate and inaccurate communication. Every individual in the system, especially managers, are affected by this issue.

School administrators should not choose neurotic personalities to function as leaders. An increase this personality or having such behaviour reduces the managerial leadership qualities in managers and makes management difficult.

School administrators should be provided with in-service training before becoming managers.Furthermore, systems should be arranged for masters-level and doctoral education in the academic field. Since the increase in the quality of education depends on an increase in managerial and teacher qualifications, an incentives system should be developed.

Personality and leadership characteristics are very important in business life, education and other fields. Individuals can develop these two characteristics by increasing their knowledge and skills. Today, the humanitarian crisis is dominant, so people that have personality (character) are needed. The progress of society and the state is also a result of these people being leaders. For this reason, all people in the education system, especially administrators, should be informed about personality and its relation to servant leadership and should be guided by activities oriented towards that practise.

The data related to the research were collected by quantitative methods. Performing various studies using qualitative research and mixed research methods will provide more data on personality and servant leadership. The data obtained by different methods will lead to more effective use of leadership and personality theories in practise.

The opinions of the teachers were the only ones used in this research. In personality and leadership surveys, data is received either from people or from their environment. This research was conducted by obtaining data from opinions of teachers. In research, a comprehensive study can be conducted not only with teachers or administrators but also with school staff and students.

Research was conducted using limited demographic variables such as gender, marital status, educational status, education level and duration of service. Future rearch could be performed in the context of different variables.

\section{Acknowledgements}

A part of this paper was presented at the International Academic Conference on Teaching, Learning and E-learning in Budapest, Hungary 2017 (IAC-TLEl 2017) between 14 and 15 April 2017.

\section{References}

Bacanl, H., Ilhan, T., \& Aslan, S. (2009). Development of a personality scale based on five factor theory: adjective based personality test (ABPT). Turkish Education Science Journal, Spring, 7(2), 261-279.

Bartone, P. T., Eid, J., Johnsen, H. B., Laberg, J. C., \& Snook, S. A. (2009). Big five personality factors, hardiness and 
social judgment as predictors of leader performance. Leadership \& Organization Development Journal, 30(6), 498-521. https://doi.org/10.1108/01437730910981908

Black, G. L. (2007). A correlational analysis of servant leadership and school climate. University of Phoenix. http://pqdtopen.proquest.com/doc/193495440.html?FMT=AI

Brown, G. A. (2010). Teachers' perceptions of the importance of identified servant leadership characteristics for high school principals in two diverse communities. Thesis, State University, Virginia Polytechnic Institute Institutional Review

Board.

https://theses.lib.vt.edu/theses/available/etd-03182010-211048/unrestricted/BROWN_GA_D_2010.pdf

Burger, J. M. (2011). Personality. New York: Cengage Learning.

Casson, H. N. (2006). İnsan Yönetme Sanatı. İstanbul: Bilge Matbaacılık.

Cavazottea, F., Morenob, V., \& Hickmannb, M. (2011). Effects of leader intelligence, personality and emotional intelligence on transformational leadership and managerial performance. The Leadership Quarterly, 23(3), 443455. https://doi.org/10.1016/j.leaqua.2011.10.003

Çiğdem, Ş. (2013). A qualitative research on the factors that lead their leaders to servant leadership behavior. Unpublished Master's thesis. Gaziantep University, Social Sciences Institute, Gaziantep.

Dennis, R. S., \& Bocernea, M. (2005). Development of the servant leadership, an assessment instrument. Leadership and Organization Development Journal, 26(8), 600-615. https://doi.org/10.1108/01437730510633692

Eren, E. (2015). Örgütsel davranış ve yönetim psikolojisi. İstanbul: Beta.

Farling, M. L., Stone, A. G., \& Winston, B. E. (1999). Servant leadership: setting the stage for empirical research. The Journal of Leadership Studies, 6(1), 49-72. https://doi.org/10.1177/107179199900600104

Fındıkçı, İ. (2012). Bir gönül yolculuğu, hizmetkâr liderlik. İstanbul: Alfa Yayınları.

Graham, J. W. (1991). Servant leadership in organizations. Inspirational and Moral, Leadership Quarterly, 2(2), 105-119. https://doi.org/10.1016/1048-9843(91)90025-W

Greenleaf, R. K. (1970). The Servant as Leader. Business Leadership, Jossy Bass: pp. 117-136.

Hoy, W. K., \& Miskel, C. G. (2015). Eğitim yönetimi teori, araştırma ve uygulama. Ankara: Nobel Yayıncılık.

Joseph E., \& Winston B. A. (2005). Correlation of servant leadership, leader trust and organizational trust. Leadership \& Organizational Development Journal, 26(1), 6-22. https://doi.org/10.1108/01437730510575552

Judge, T. A., Bono, J. E., Ilies, R., \& Gerhardt, M. W. (2002). Personality and leadership: A qualitative and quantitative review. Journal of Applied Psychology, 87(4), 765-780. https://doi.org/10.1037/0021-9010.87.4.765

Kalshoven, K., Den Hartog, D. N., \& De Hoogh, A. H. B. (2011). Ethical leader behavior and big five factors of personality. Journal of Business Ethics, 100(2), 349-366. https://doi.org/10.1007/s10551-010-0685-9

Karasar, N. (2008). Bilimsel araştırma yöntemi, kavramlar, ilkeler, teknikler. Ankara: Nobel yayınları.

Konan, N., Demir, H., \& Karakuş, M. (2015). A study of Turkish adaptation of executive servant leadership scale into Turkish. Electronic International Journal of Education, Arts and Science, 1(1), 135-155.

Laub, J. A. (1999). Assessing the servant organization: development of the servant organizational leadership. Assessment (Sola) Instrument, Dissertation Abstracts International, 60(2), 992-1922.

Lunenburg, F. C., \& Ornstein A. C. (2013). Eğitim yönetimi. Ankara: Nobel Yayıncılık.

Page, D., \& Wong, P. T. (2000). A Conceptual Framework for Measuring Servant-Leadership. Trinity Western University: Langley, B. C.

Parolini, J. (2007). Investigating the distinctions between transformational and servant leadership. Unpublished doctoral dissertation, Regent University, Virgina Beach, VA.

Patterson, K. (2003). Servant leadership: a theoetical model. Unpublished doctoral dissertation, Regent University, Servant Leadership Research Roundtable, The School of Leadership Studies, Virginia.

Russell, R. F. (2001). The role of values in servant leadership. Leadership and Organization Development Journal, 22(2), 76-83. https://doi.org/10.1108/01437730110382631

Saylı, H., \& Baytok, A. (2013). Örgütlerde liderlik teori uygulama ve yeni perspektifler. Nobel Yayınc1lı: Ankara.

Spears, L. C. (1995). Reflections on Leadership: How Robert K. Greenleaf's Theory of Servant Leadership Influenced Today's Top Management Thinkers. New York: John Wiley \& Sons. 
Valentine, J. (2007). An analysis of the relationships between servant leadership, school culture, and student achievement. Thesis (Ph. D.) University of Missouri-Columbia 2007, University of Missouri, Columbia, Educational leadership and policy analysis. https://mospace.umsystem.edu/xmlui/handle/10355/4657?show=full

Vinod, S., \& Sudhakar, B. (2011). Servant leadership: A unique art of leadership. Interdisciplinary Journal of Contemporary Research in Business, 2(11), 456-467.

Wong, P. T., \& Davey, D. (2007). Best Practices in Servant Leaderhip. Virginia Beach (VA): Regent University.

Yazgan, İ. B., \& Yerlikaya, E. E. (2012). Kişilik kuramları. Ankara: Pegem Akademi.

Yıldırım, A., \& Şimşek, H. (2013). Sosyal bilimlerde nitel araştırma yöntemleri. Ankara: Seçkin Yayıncılık.

Y1lmaz, C. (2013). The Relationship between servant leadership and organizational commitment. Unpublished Master's thesis. Gebze Advanced Technology Institute, Institute of Social Sciences, Gebze.

Yukl, G. (2010). Leadership in Organizations, Global Edition. 7.B. Upper Saddle River: Pearson.

Zel, U. (2011). Kişilik ve liderlik: evrensel boyutlarıyla yönetsel açıdan araştırmalar, teoriler ve yorumlar. Ankara: Seçkin Yayıncılık.

\section{Copyrights}

Copyright for this article is retained by the author(s), with first publication rights granted to the journal.

This is an open-access article distributed under the terms and conditions of the Creative Commons Attribution license which permits unrestricted use, distribution, and reproduction in any medium, provided the original work is properly cited. 